\title{
Replacement of cereal grains by orange pulp and carob pulp in faba bean-based diets fed to lambs: effects on growth performance and meat quality
}

\author{
Massimiliano LANZA ${ }^{\mathrm{a} *}$, Alessandro PRIOLO ${ }^{\mathrm{a}}$, Luisa BIONDI ${ }^{\mathrm{a}}$, \\ Marco BeLlA ${ }^{\mathrm{a}}$, Hichem BeN SALEM ${ }^{\mathrm{b}}$ \\ ${ }^{a}$ Istituto di Scienze e Tecnologie delle Produzioni Animali, Facoltà di Agraria, \\ Università di Catania, Via Valdisavoia 5, 95123 Catania, Italy \\ b Institut National de la Recherche Agronomique de Tunisie, Laboratoire de Nutrition Animale, \\ rue Hédi Karray, 2049 Ariana, Tunisia
}

(Received 15 February 2000; accepted 14 September 2000)

\begin{abstract}
Fourteen weaned lambs (43 days of age) were divided into two equal groups of seven animals and received two different diets. The experimental diet contained $10 \%$ of carob pulp and $10 \%$ of orange pulp associated to $54 \%$ of faba bean. The control diet contained $12 \%$ of maize meal and $12 \%$ of barley meal associated to $49.2 \%$ of faba bean. Both diets were pelletted and given ad libitum. The two diets had comparable contents of dry matter, ash, crude fat, fibre and crude protein. Control diet was relatively higher in soluble nitrogen than the experimental one. However, experimental diet was higher in fibre-bound nitrogen and in total and condensed tannins than control one. At the end of the feeding trial (120 d of age) growth and slaughter performance were comparable between treatments. Chemical analysis of meat samples did not show any significant difference between groups. Physical analysis of meat showed a higher $(P<0.05)$ lightness $\left(\mathrm{L}^{*}\right)$ value in experimental group than in the control one. Sensory analysis allowed the panellists to discriminate lamb meat from the two groups. Flavour, tenderness and juiciness were judged to be more intense $(P<0.01)$ in the meat of control group; also overall acceptability was higher $(P<0.05)$ in this group. It was concluded that the replacement of cereal grains with carob and orange pulp in lamb fattening diet is useful to reduce feeding costs. Nevertheless, we need further investigations on the level of inclusion in the diet, in order to avoid the negative effects on sensory attributes without detrimental effect on growth performance.
\end{abstract}

cereal grains / orange pulp / carob pulp / growth / meat quality / sheep

Résumé - Remplacement des grains de céréales par la pulpe d'orange et la pulpe de caroube dans des régimes à base de féverole destinés aux agneaux. Effets sur la croissance et la qualité de la viande. Quatorze agneaux sevrés et âgés de 43 jours ont été répartis en deux lots homogènes.

* Correspondence and reprints

Tel.: (39) 095 234341; fax: (39) 095 234345; e-mail: malanza @ mbox.fagr.unict.it 
Un lot a reçu une ration contenant $10 \%$ de pulpe d'orange, $10 \%$ de pulpe de caroube, et $54 \%$ de féverole (lot expérimental), l'autre lot a reçu un régime composé de $12 \%$ de maïs, $12 \%$ d'orge, et $49,2 \%$ de féverole (lot témoin). Chaque régime a été distribué aux animaux sous forme de granulés distribués à volonté. Les deux régimes avaient des teneurs en matière sèche, en cendres, en matière grasse, en fibres et en matières azotées totales comparables. La fraction d'azote soluble a été relativement plus élevée dans le régime témoin par rapport au régime expérimental. En revanche, les teneurs en azote lié aux fibres et aux tannins totaux et condensés ont été plus importantes dans le régime expérimental. À la fin de l'essai d'alimentation (âge 120 j), les deux lots ont eu les mêmes performances de croissance. L'analyse chimique de la viande, n'a révélé aucune différence entre les deux lots d'animaux. La viande issue du lot expérimental a été plus claire $\left(\mathrm{L}^{*}, P<0,05\right)$ que celle du lot témoin. La flaveur, la tendreté et la jutosité évaluées par analyse sensorielle ont été plus intenses dans la viande du lot témoin par rapport à celle de la viande du lot expérimental $(P<0,01)$. Ces différences concourent à expliquer la meilleure acceptabilité de la viande des animaux recevant le régime témoin par rapport à celle de la viande des animaux recevant le régime expérimental $(P<0,05)$. Ce travail permet de conclure que le remplacement des aliments concentrés conventionnels par les pulpes d'orange et de caroube dans des régimes d'engraissement d'agneau permet de réduire le coût de l'alimentation mais il reste encore à déterminer le niveau optimal de leur incorporation qui permettrait d'éviter à la fois les effets négatifs sur la qualité sensorielle de la viande et ceux sur les performances de croissance.

grains de céréales / pulpe d'orange / pulpe de caroube / croissance / qualité de la viande / mouton

\section{INTRODUCTION}

In Sicily, the fattening diets fed to lambs are characterised by the association of local forages and concentrates based on imported soybean meal as the main protein source and cereal grains as the main carbohydrates sources. An important objective in livestock feeding is to promote the use of local feeds and by-products in order to reduce feeding costs. However, the effects of using such feeds on growth performance and meat quality have been little studied.

Faba bean (Vicia faba var. minor) is a legume seed largely diffused in the Mediterranean area and is relatively cheap despite its relatively high nutritional value [8]. Its crude protein appears to be reasonably well balanced with regard to aminoacidic composition and the starch content is relatively high. The use of a lamb fattening diet largely based on faba bean gave similar growth performance and meat characteristics compared to the traditional diets based on soybean meal as main protein source $[6,15,23]$.

Orange pulp and carob pulp are by-products widely available in the Mediterranean area and are valuable sources of pectins and soluble carbohydrates [13]. In a previous experiment Lanza et al. [15] found that a diet based on faba bean contained a high level of nonprotein nitrogen (NPN), denoted as A-nitrogen fraction, immediately degradable in the rumen. Therefore, it is reasonable to expect a good efficiency in ruminal protein synthesis when faba bean is associated to feeds containing rapidly fermentable carbohydrates, such as orange pulp and carob pulp.

The objective of the present work was to compare the effects of the combined inclusion of orange pulp and carob pulp in replacement of barley and maize in a pelletted diet, with faba bean as the main protein source, on lamb growth performance and on carcass and meat quality. 


\section{MATERIALS AND METHODS}

\subsection{Animals, diets and procedures at the abattoir}

The trial was conducted at the experimental station of the "Facoltà di Agraria", University of Catania (Italy), and involved 14 intact male Barbaresca lambs. The animals were born in a farm located in eastern Sicily within a 7-day period and were reared under their dams until weaning at 43 days of age. From the second week of age they were allowed a commercial starter concentrate and grass hay. After weaning, the lambs were divided into two comparable groups of seven animals with the same live weight and penned collectively into two different stalls indoor for the whole fattening period.

From the 43rd to the 50th day the lambs were gradually adapted to the fattening diets. The control group (CG) was fed a complete pelletted diet with maize meal and barley meal associated to faba bean (Vicia faba var. minor). The experimental group (BP) was fed a complete pelletted diet in which orange pulp and carob pulp were both present in the amount of $10 \%$ (on an as-fed basis) each in the diet, replacing all the cereals of the control diet. Both diets, that were supplied ad libitum, had also $20 \%$ of wheat straw. All the ingredients were ground by a feed mill and steam pelletting was carried out without inclusion of binding agents. Fresh feed was supplied once daily at $09.00 \mathrm{~h}$ and the refusal was collected at same time to calculate voluntary feed intake and feed conversion ratio. Lambs were individually weighed once weekly. The composition of diets and the chemical analysis are shown in Table I.

Lambs were slaughtered, after electrical stunning, by throat cut at 120 days of age.

Ruminal fluid $\mathrm{pH}$ was measured immediately after slaughter by an Orion 210A pH meter equipped with an Orion 9106 glass electrode. The hot carcasses were weighed and assessed for fatness, estimated by two experts using a 15-point scale as described by Dransfield et al. [10]. The carcasses were then chilled in a room at $4{ }^{\circ} \mathrm{C}$.

\subsection{Laboratory analyses}

Feed crude protein, ether extract and ash contents were analysed according to AOAC [1]. Fibre fractions were evaluated according to Goering and Van Soest [12] while protein fractions according the following procedures described by Licitra et al. [16]. Nonprotein nitrogen (or A nitrogen fraction) was detected by tungstic acid procedure and calculated as the difference between the total crude protein nitrogen (Kjeldhal procedure) and the value of the true protein nitrogen precipitated with tungstic acid. Soluble protein was detected by buffer-soluble nitrogen procedure. It is soluble in borate-phosphate buffer at rumen $\mathrm{pH}$ and is calculated by subtracting bufferinsoluble residue from total crude protein. The true soluble protein, denoted as $\mathrm{B}_{1}$ nitrogen fraction, can be obtained by subtracting the buffer-insoluble nitrogen residue from the true protein. The nitrogen associated with NDF is cell wall-bound protein which includes the indigestible nitrogen found in the acid-detergent residue. Both NDIN (neutral-detergent insoluble nitrogen) and ADIN (acid-detergent insoluble nitrogen) were obtained by the alternate procedure using Fibertec apparatus, described by Licitra et al. [16]. The neutral detergent soluble protein denoted as $\mathrm{B}_{2}$ nitrogen fraction is obtained by subtracting neutral detergent insoluble protein from buffer-insoluble nitrogen residue. The protein insoluble in neutral-detergent but soluble in acid-detergent solution is denoted as $\mathrm{B}_{3}$ nitrogen fraction. It is obtained by subtracting ADIN from NDIN. The acid-detergent insoluble nitrogen (ADIN) denoted as $\mathrm{C}$ nitrogen fraction include heat-damaged protein and nitrogen associated with lignin. Triplicate feed samples (about $200 \mathrm{mg}$ ) were extracted in aqueous acetone $(70: 30 \mathrm{v} / \mathrm{v})$. Extractable 
Table I. Composition of the diets.

\begin{tabular}{|c|c|c|c|}
\hline \multirow{2}{*}{\multicolumn{2}{|c|}{ Diet components (\%, weight basis) }} & \multicolumn{2}{|c|}{ Diet treatment } \\
\hline & & $\mathrm{BP}$ & $\mathrm{CG}$ \\
\hline \multicolumn{2}{|l|}{ Faba bean } & 54.0 & 49.2 \\
\hline \multicolumn{2}{|l|}{ Barley } & - & 12.0 \\
\hline \multicolumn{2}{|l|}{ Maize } & - & 12.0 \\
\hline \multicolumn{2}{|l|}{ Orange pulp } & 10.0 & - \\
\hline \multicolumn{2}{|l|}{ Carob pulp } & 10.0 & - \\
\hline \multicolumn{2}{|l|}{ Brewer's yeast } & 3.0 & 3.0 \\
\hline \multicolumn{2}{|l|}{ Wheat straw } & 20.0 & 20.0 \\
\hline \multicolumn{2}{|l|}{ Vitamin-mineral premix } & 3.0 & 3.8 \\
\hline \multicolumn{4}{|l|}{ Chemical composition } \\
\hline Moisture & $\%$ & 12.91 & 12.58 \\
\hline Crude protein & $\% \mathrm{DM}$ & 17.44 & 18.24 \\
\hline Soluble protein & $\% \mathrm{CP}$ & 25.70 & 35.49 \\
\hline $\mathrm{N}-\mathrm{NDF}$ & $\% \mathrm{CP}$ & 15.38 & 11.00 \\
\hline \multicolumn{4}{|l|}{ Protein fractions: } \\
\hline A & $\% \mathrm{CP}$ & 20.07 & 27.54 \\
\hline $\mathrm{B}_{1}$ & , & 5.63 & 7.95 \\
\hline $\mathrm{B}_{2}$ & $"$ & 58.92 & 53.51 \\
\hline $\mathrm{B}_{3}^{2}$ & $"$ & 9.25 & 7.54 \\
\hline $\mathrm{C}^{3}$ & ", & 6.13 & 3.46 \\
\hline $\mathrm{NDF}$ & $\% \mathrm{DM}$ & 27.74 & 29.47 \\
\hline $\mathrm{ADF}$ & $"$ & 19.02 & 17.56 \\
\hline ADL & $"$ & 4.00 & 2.67 \\
\hline Crude lipids & $"$ & 1.03 & 1.50 \\
\hline Ash & $”$ & 9.14 & 7.57 \\
\hline Total phenols & g equivalent tannic acid $\cdot \mathrm{kg}^{-1} \mathrm{DM}$ & 10.10 & 7.50 \\
\hline Total tannins & $"$ & 1.90 & 0.20 \\
\hline Condensed tannins & $\mathrm{g}$ equivalent leucocyanidin $\cdot \mathrm{kg}^{-1} \mathrm{DM}$ & 3.80 & 2.10 \\
\hline Metabolisable energy & $\mathrm{MJ} \cdot \mathrm{kg}^{-1} \mathrm{DM}$ & 7.19 & 8.49 \\
\hline Gas $24 \mathrm{~h}$ - without PEG & $\mathrm{ml} \cdot 200 \mathrm{mg}^{-1} \mathrm{DM}$ & 31.40 & 38.60 \\
\hline Gas $24 \mathrm{~h}$ - with PEG & $\mathrm{ml} \cdot 200 \mathrm{mg}^{-1} \mathrm{DM}$ & 33.20 & 38.50 \\
\hline
\end{tabular}

BP: experimental group; CG: control group; $A$ : non protein nitrogen; $\mathrm{B}_{1}$ : true soluble protein; $\mathrm{B}_{2}$ : neutral detergent soluble protein; $\mathrm{B}_{3}$ : protein insoluble in neutral-detergent but not in acid-detergent solution; $\mathrm{C}$ : acid-detergent insoluble nitrogen.

total phenols and total and condensed tannins were analysed on the respective supernatants as described by Makkar and Goodchild [17]. The in vitro incubation system (gas in calibrated syringe) was used to measure gas production from feeds. The rumen liquor was obtained from the rumens of two sheep receiving oat hay ad libitum and a mixture of $200 \mathrm{~g}$ processed barley and
$100 \mathrm{~g}$ soybean meal per head. Buffer solutions and rumen liquor / buffer $(1: 2 \mathrm{v} / \mathrm{v})$ were prepared as described by Menke and Steingass [18]. After weighing in duplicate about $200 \mathrm{mg}$ DM of cereal diet or by-product one with $(100 \mathrm{mg}$ ) or without PEG-4000 into calibrated syringes $(100 \mathrm{ml})$, the pistons were lubricated with Vaseline to ease their sliding and to prevent escape of gas. 
The syringes were prewarmed $\left(40{ }^{\circ} \mathrm{C}\right)$ before the injection of $30 \mathrm{ml}$ of rumen liquor per buffer mixture into each syringe, followed by incubation in a ventilated oven $\left(39^{\circ} \mathrm{C} \pm 1{ }^{\circ} \mathrm{C}\right)$. The syringes were gently shaken $30 \mathrm{~min}$ after the start of incubation and then every hour during the first $10 \mathrm{~h}$ of incubation. Readings were recorded after $24 \mathrm{~h}$ incubation period.

Metabolisable energy (ME, $\left.\mathrm{MJ} \cdot \mathrm{kg}^{-1} \mathrm{DM}\right)$ of feeds was estimated using the equation developed by Menke and Steingass [18]: $\mathrm{ME}=1.39+0.1457 \mathrm{Gv}+0.0075 \mathrm{CP}+3.14 /$ $\mathrm{CP}+0.0119($ Fat $)+0.00008311(\text { Fat })^{2}$. The $\mathrm{Gv}$ is the net volume, in $\mathrm{ml}$, of gas produced in $24 \mathrm{~h}$ and $\mathrm{CP}$ in $\mathrm{g} \cdot \mathrm{kg}^{-1} \mathrm{DM}$. Gv was computed as follows: $\mathrm{Gv}=(\mathrm{G} 24-\mathrm{G} 0-\mathrm{Gb}) /(\mathrm{FH}$ $+\mathrm{FHS}) / 2$; where G24 and G0 are gas produced in 24 and $0 \mathrm{~h}$, respectively, $\mathrm{Gb}$ gas produced in blank syringes (rumen fluid and buffer without substrate), FH stands for standard hay and FHS for standard concentrate and hay mixture.

\subsection{Meat quality}

At $24 \mathrm{~h}$ post mortem the $\mathrm{pH}$ was measured in the longissimus thoracis by an Orion 9106 penetrating glass electrode using an Orion $210 \mathrm{~A} \mathrm{pH}$ meter. At $72 \mathrm{~h}$ post mortem, carcasses were split into two sides. From each right side the hind leg was separated and dissected according to ASPA [2] to determine lean, separable fat and bone proportions. The longissimus thoracis and lumborum muscles were then separated to evaluate meat quality.

Physical and chemical analyses were performed on the longissimus thoracis. Colour was measured according to CIE (L*a*b*) system on $3-\mathrm{cm}$ thick muscle slices cut $72 \mathrm{~h}$ post mortem using a colour meter Minolta CR 300 (light source: $\mathrm{C}=6740^{\circ} \mathrm{K}$ ) calibrated to a standard white tile. Samples were stored for $2 \mathrm{~h}$ on a polystyrene tray wrapped in a polyethylene film at $4{ }^{\circ} \mathrm{C}$ before evaluation. Chroma $\left(\mathrm{C}^{*}\right)$ and hue angle $\left(\mathrm{H}^{*}\right)$ were also calculated.
Water holding capacity was evaluated as the cooking loss measured according to Boccard et al. [5]. Meat samples (about $55 \mathrm{~g}$ ) were weighed and held in plastic bags and then immersed in a water-bath at $75^{\circ} \mathrm{C}$ until the internal temperature reached $75^{\circ} \mathrm{C}$ as monitored with a thermocouple. Then the bags were cooled under running tap water for $30 \mathrm{~min}$ and then blotted dry with paper towels and reweighed.

Shear force (WBS) was evaluated on a meat sample cooked as describe above. Three strips $(1 \times 1 \mathrm{~cm})$ were removed from each cooked sample parallel to muscle fibres and sheared perpendicularly to the direction of the fibres using an Instron universal testing machine (Instron 4411) equipped with a Warner-Bratzler shearing device.

Before chemical analyses, all samples were stored at $-24{ }^{\circ} \mathrm{C}$. Moisture, fat and ash contents were determined on raw minced samples according to AOAC [1], while protein content was calculated by difference.

\subsection{Sensory analysis}

The lumbar region of the longissimus muscle was used for sensory analysis. Meat samples aged for $72 \mathrm{~h}$, were frozen at $-24^{\circ} \mathrm{C}$ until taste panel evaluation. Samples were thawed at $4{ }^{\circ} \mathrm{C}$ the day before panel session. The samples were held in plastic bags and cooked in a boiling water-bath until the internal temperature reached $75^{\circ} \mathrm{C}$ monitored using a probe and a recording thermometer. Samples were trimmed free of all subcutaneous fat and epimysial connective tissue before they were served warm to the sensory panel. The samples were randomly assessed during two panel sessions. The samples were scored for flavour, tenderness, juiciness and overall acceptability by a 10-member trained panel using a 9-point intensity scale ( 9 being the most flavoured, tender, juicy and acceptable and 1 being the less flavoured, tender, juicy and acceptable). 


\subsection{Statistical analysis}

All data were processed by $t$ test to compare the two diets. For sensory analysis we used a two way ANOVA with diet and panellist as factors. Statistical analysis was performed on MINITAB statistical software[19].

\section{RESULTS AND DISCUSSION}

\subsection{Characteristics of the two diets}

Both diets had similar crude protein and NDF concentration (Tab. I). The soluble protein content ( $\mathrm{A}+\mathrm{B}_{1}$ fractions) was $27.6 \%$ lower in the BP-diet than in the CG-diet. The fibre-bound nitrogen content (N-NDF) was $39.8 \%$ higher in the BP diet than in the CG one. The BP diet showed a higher $\mathrm{B}_{2}$ (neutral detergent soluble protein), $B_{3}$ (neutral detergent insoluble protein) and $\mathrm{C}$ (acid detergent insoluble protein) protein fractions contents than control diet. The higher concentration in $\mathrm{C}$ protein fraction in by-product diet can be due to the presence of condensed tannins in carob pulp and/or to the heat treatment effect on orange pulp before its inclusion in pelletted diet. Acid detergent lignin content in the BP diet was much higher than in CG because of the presence of carob pulp which contains high proportions of ADL [20]. However, the BP diet showed a better repartition in protein fractions than the CG one. Total phenols and total tannins were higher in the BP diet as expected for the presence of carob pulp associated to faba bean. The BP diet was richer in condensed tannins (3.8 vs. $2.1 \mathrm{~g}$ equivalent leucocyanidin per $\mathrm{kg} \mathrm{DM}$ ) than control. Condensed tannins are powerful protein binding agents in the rumen, reducing protein degradability. Condensed tannins from carob pulp, besides, are particulary deleterious on diet digestibility and lamb growth [21]. The use of calibrated glass syringes [18] to evaluate in vitro gas production is widely used to estimate metabolisable energy (ME) in feedstuffs and to assess effects of tannins on their feeding value. Gas volume was higher in the control diet than in the by-product containing one (Tab. I). Estimated ME content was $18.1 \%$ higher for control diet than for experimental diet. This may be explained by the lower condensed tannins content. It is well established that carob pulp is high in condensed tannins in a range between $3.8 \%$ of DM [7] and $5.3 \%$ of DM [20] which reduce its nutritive value [20]. Response to PEG in terms of gas production was more pronounced with orange and carob pulps containing diets than with cereal grain containing diet.

\subsection{Growth and slaughter performances}

No significant difference was shown in the lamb final live weight and average daily weight gain between treatments. Dry matter intake and feed conversion ratio were similar in the two groups (Tab. II).

Empty live weight, carcass weight and net dressing percentage were comparable between treatments. No difference was observed in carcass fatness. The carcasses of both groups showed a considerable fatness score (4+ and 4- according to the SEUROP grading system) although it is acceptable for Mediterranean consumers. These values are higher than those obtained in a previous trial in which Barbaresca lambs were slaughtered at $100 \mathrm{~d}$ of age [15]. Slaughter age plays an important role in the development of carcass fatness and it is associated to the increase in the animal live weight [4, $11,25]$.

Ruminal fluid $\mathrm{pH}$ was similar between groups (5.41 and 5.62 for CG and BP, respectively). These values are lower than those reported by Ben-Ghedalia et al. [3] in two-year old Merino rams fed two diets with $84.4 \%$ and $20.4 \%$ of citrus pulp and rationed lucerne hay. Our values are probably due to the lack of structured fibre in the diets because of the high grinding level of feeds 
Table II. Growth and slaughter performances.

\begin{tabular}{|c|c|c|c|c|}
\hline \multirow[t]{2}{*}{ Traits } & \multicolumn{2}{|c|}{ Diet treatment } & \multirow[t]{2}{*}{ SEM } & \multirow[t]{2}{*}{ Significance level } \\
\hline & BP & CG & & \\
\hline Number of animals & 7 & 7 & & \\
\hline Live weight at weaning (kg) & 12.5 & 12.6 & 0.537 & NS \\
\hline Live weight at $50 \mathrm{~d}(\mathrm{~kg})$ & 12.7 & 12.5 & 0.579 & NS \\
\hline Final live weight $(\mathrm{kg})$ & 30.2 & 29.9 & 1.460 & NS \\
\hline Average daily gain $50-120 \mathrm{~d}\left(\mathrm{~g} \cdot \mathrm{d}^{-1}\right)$ & 250 & 249 & 0.015 & NS \\
\hline Dry matter intake $50-120 \mathrm{~d}\left(\mathrm{~g} \cdot \mathrm{d}^{-1}\right)$ & 1124 & 1176 & & \\
\hline Dry matter intake/live weight gain $\left(\mathrm{kg} \cdot \mathrm{kg}^{-1}\right)$ & 4.49 & 4.72 & & \\
\hline Empty live weight at slaughter $(\mathrm{kg})$ & 26.5 & 26.5 & 1.280 & NS \\
\hline Warm carcass weight (kg) & 13.3 & 13.5 & 0.689 & NS \\
\hline Net dressing percentage $(\%)$ & 50.19 & 50.68 & 0.302 & NS \\
\hline Carcass fatness, score (1 to 15 ) & 10.29 & 10.17 & 0.416 & NS \\
\hline Rumen fluid $\mathrm{pH}$ & 5.62 & 5.41 & 0.132 & NS \\
\hline
\end{tabular}

NS: not significant.

before pelletting. Because of the accordance of growth and carcass performances with the growth potential for Barbaresca breed, in our opinion these very low $\mathrm{pH}$ values of ruminal fluid do not represent a problem for young growing lambs destined to the slaughterhouse. There was no significant difference between treatments with regard to ruminal fluid volatile fatty acids (data not shown).

There was no significant difference in leg weight and in lean, fat and bone percentages between treatments (Tab. III). Lean/fat and lean/bone ratios were also comparable. In a previous work [15] the use of a diet with faba bean as the major diet ingredient, decreased the proportion of edible parts (lean + fat), compared to a traditional diet (soybean and cereals). The association of different carbohydrates sources, such as cereal grains or citrus pulp and carob pulp, with faba bean seems to be more efficient than diets almost totally based on faba bean.

\subsection{Effect of diets on chemical and physical characteristics of longissimus muscle}

In Table IV are shown the meat chemical and physical characteristics. Chemical analysis did not show any significant difference between treatments. However crude fat content was slightly higher in BP lamb meat than in CG one $(2.79 \%$ vs. $1.94 \%)(P<0.10)$ and ash content was slightly higher in $\mathrm{CG}$ lamb meat than in $\mathrm{BP}$ one $(P<0.10)$.

Meat ultimate $\mathrm{pH}$ values were similar between the two groups (average 5.64) and within the normal range for mutton. Similar ultimate $\mathrm{pH}$ values between groups indicate that there was no difference, due to the diet, in the muscle glycogen content at slaughter .

Lightness $\left(\mathrm{L}^{*}\right)$ was significantly $(P<0.05)$ different between treatments and was not correlated to $\mathrm{pH}$ values $(r=0.10 ; P>0.05)$. Lambs fed BP diet showed a lighter meat than lambs fed CG diet. Probably the presence of carob pulp, that contains condensed tannins, in BP diet could explain this result as reported by Priolo et al. [21]. Also, the slightly higher fat level in the longissimus muscle of BP lambs could contribute to the higher values of lightness. The meat that is lighter meets consumer's preferences better than the darker one, probably because consumers associate freshness to a lighter meat. No difference was found between treatments in $\mathrm{a}^{*}$ (redness) and $\mathrm{b}^{*}$ (yellowness), hue or chroma values. 
Table III. Anatomical composition of the hind leg.

\begin{tabular}{|c|c|c|c|c|}
\hline \multirow[t]{2}{*}{ Traits } & \multicolumn{2}{|c|}{ Diet treatment } & \multirow[t]{2}{*}{ SEM } & \multirow[t]{2}{*}{ Significance level } \\
\hline & $\mathrm{BP}$ & $\mathrm{CG}$ & & \\
\hline Leg weight (kg) & 1.73 & 1.70 & 0.084 & NS \\
\hline Lean (\% leg weight) & 59.36 & 59.80 & 0.802 & NS \\
\hline Fat (\% leg weight) & 13.38 & 12.87 & 0.615 & NS \\
\hline Bone (\% leg weight) & 27.25 & 27.32 & 0.736 & NS \\
\hline Lean/fat & 4.62 & 4.73 & 0.236 & NS \\
\hline Lean/bone & 2.19 & 2.22 & 0.072 & NS \\
\hline
\end{tabular}

NS: not significant.

Table IV. Chemical and physical characteristics of the longissimus muscle.

\begin{tabular}{|c|c|c|c|c|}
\hline \multirow[t]{2}{*}{ Traits } & \multicolumn{2}{|c|}{ Diet treatment } & \multirow[t]{2}{*}{ SEM } & \multirow[t]{2}{*}{ Significance level } \\
\hline & $\mathrm{BP}$ & CG & & \\
\hline Moisture content (\%) & 75.21 & 75.47 & 0.227 & NS \\
\hline Crude fat content ${ }^{\mathrm{a}}(\%)$ & 2.79 & 1.94 & 0.256 & NS \\
\hline Ash content $\mathrm{t}^{\mathrm{a}}(\%)$ & 1.02 & 1.14 & 0.033 & NS \\
\hline Protein content ${ }^{\mathrm{a}}(\%)$ & 21.46 & 20.98 & 0.178 & NS \\
\hline $\mathrm{pH}$ & 5.65 & 5.63 & 0.011 & NS \\
\hline L* (lightness) & 45.27 & 43.64 & 0.393 & $*$ \\
\hline $\mathrm{a}^{*}$ (redness) & 15.01 & 15.50 & 0.431 & NS \\
\hline b* (yellowness) & 6.57 & 6.83 & 0.281 & NS \\
\hline Hue & 23.62 & 23.75 & 0.648 & NS \\
\hline Chroma & 16.39 & 16.96 & 0.479 & NS \\
\hline Cooking loss (\%) & 11.25 & 11.43 & 0.739 & NS \\
\hline Warner-Bratzler shear force $\left(\mathrm{kg} \cdot \mathrm{cm}^{-2}\right)$ & 6.22 & 6.01 & 0.615 & NS \\
\hline
\end{tabular}

$* P<0.05$; NS: not significant.

a Fresh matter basis.

There was no difference in cooking loss between treatments. Cooking losses are mostly influenced by intramuscular fat content. In the present experiment there was a negative relationship $(r=-0.76 ; P<0.01)$ between cooking loss and intramuscular fat which agrees with the literature [14, 22].

Shear force values were not affected by the diet treatment. These values were higher than those obtained in a previous study [15] on Barbaresca lambs slaughtered at 100 days of age, fed a diet largely based on faba bean.
However, they still indicate a tender meat according to Devine et al. [9] which assessed that shear force values below $8 \mathrm{kgF}$ are highly acceptable and that the most tender meat came from young lambs with an ultimate $\mathrm{pH}$ from 5.5-5.7.

\subsection{Effect of diets on sensory analysis of longissimus muscle}

Table V shows the results of the sensory evaluation. There were significant differences 
Table V. Sensory analysis results (1- to 9-point scale).

\begin{tabular}{|c|c|c|c|c|c|}
\hline \multirow[t]{2}{*}{ Traits } & \multicolumn{2}{|c|}{ Diet } & \multicolumn{2}{|c|}{ Significance level } & \multirow[b]{2}{*}{ SEM } \\
\hline & $\mathrm{BP}$ & $\mathrm{CG}$ & Diet & Panellist & \\
\hline Flavour & 5.99 & 6.57 & $* *$ & $* * *$ & 0.715 \\
\hline Tenderness & 5.90 & 7.10 & $* * *$ & $* * *$ & 0.336 \\
\hline Juiciness & 5.69 & 6.44 & $* *$ & $* * *$ & 0.251 \\
\hline Overall acceptability & 5.86 & 6.56 & $*$ & $* * *$ & 0.264 \\
\hline
\end{tabular}

$* P<0.05$; ** $P<0.01$; *** $P<0.001$.

between treatments means for all variates. Panellist effect was always significant. The scores for flavour, tenderness, juiciness and overall acceptability were significantly higher in the CG group $(P<0.01,0.001$, 0.01 and 0.05 , respectively). The panellists could clearly discriminate the meat samples from the two groups.

Intense meat flavour in grain-rich diets derive generally from methyl-branchedchain fatty acids [24]. These compounds originate from ruminal propionate. In our experiment, however, no difference was found between ruminal volatile fatty acids and we have not a plausible explanation for the different flavour intensity. The only sensory study on the effect of dietary carob pulp on mutton, showed a detrimental effect of carob tannins on meat acceptability [21]. However, in this trial the level of carob pulp was much lower than that reported by Priolo et al. [21] and is not likely to have exerted such an effect. We are not aware of studies on the acceptability of meat from lambs fed orange pulp.

Better tenderness and more intense flavour made the meat from CG lambs more acceptable than that from BP lambs as expected. However, in a 9-point scale the mean values above 5.0 for both groups indicated that the meat was acceptable and therefore the dietary effect cannot be considered detrimental.

\section{CONCLUSIONS}

The use of carob pulp and orange pulp in replacement of cereal grains in lamb fattening diets based on faba bean did not affect growth and slaughter performances. Meat from lambs fed BP diet was significantly lighter in colour than meat from lambs fed CG diet. However, the sensory evaluation analysis discriminated the meat from lambs fed BP diet, showing a negative effect of diet. On the basis of these results other studies should be undertaken to determine to which extent the level of inclusion of byproducts in lamb fattening diet should be reduced to achieve an acceptable balance between consumer meat acceptance and animal performance.

\section{REFERENCES}

[1] AOAC, Official Methods of Analysis, 16th ed., AOAC, Washington DC, 1995.

[2] ASPA (Scientific Association of Animal Production), Metodologia relativa alla macellazione degli ovi-caprini e alla valutazione e dissezione della loro carcassa (Slaughter and carcass evaluation and dissection in sheep and goat), in: Metodologie relative alla macellazione degli animali di interesse zootecnico ed alla valutazione e dissezione della loro carcassa (Slaughter and carcass evaluation and dissection procedures in livestock), ISMEA, Rome, 1991, pp. 39-45.

[3] Ben-Ghedalia D., Yosef E., Miron J., Est Y., The effects of starch- and pectin-rich diets on quantitative aspects of digestion in sheep, Anim. Feed Sci. Technol. 24 (1989) 289-298. 
[4] Biondi L., Lanza M., Priolo A., Meat and carcass quality as criteria in establishing the optima slaughtering age of Suffolk $\times$ Comisana lambs, Agric. Med. 128 (1998) 178-184.

[5] Boccard R., Buchter L., Casteels E., Cosentino E., Dransfield E., Hood D.E., Joseph R.L., Mac Dougall D.B., Rhodes D.N., Schon I., Tinbergen B.J., Touraille C., Procedures for measuring meat quality characteristics in beef production experiments. Report of a working group in the Commission of the European Communities (CEC) beef production research programme, Livest. Prod. Sci. 8 (1981) 385-397.

[6] Caballero R., Rioperez J., Fernandez E., Marin M.T., Fernandez C., A note on the use of field beans (Vicia faba) in lamb finishing diet, Anim. Prod. 54 (1992) 441-444.

[7] Calixto F.S., Cañellas J., Components of nutritional interest in carob pods (Ceratonia siliqua), J. Sci. Food Agric. 33 (1982) 1319-1323.

[8] Cevolani D., "Non sottovalutiamo le potenzialità della fava" ("Do not underestimate nutritional potential of faba bean"), Riv. Avicoltura 60 (1991) 21-23.

[9] Devine C.E., Graafhuis A.E., Muir P.D. Chrystall B.B., The effect of growth rate and ultimate $\mathrm{pH}$ on meat quality of lambs, Meat Sci. 35 (1993) 63-77.

[10] Dransfield E., Nute G.R., Hogg B.V., Walters B.R., Carcass and eating quality of ram, castrated ram and ewe lambs, Anim. Prod. 50 (1990) 291-299.

[11] Field R.A., Williams J.C., Ferrel C.L., Crouse J.D., Kunsman J.E., Dietary alteration of palatability and fatty acids in meat from light and heavy weight ram lambs, J. Anim. Sci. 47 (1978) 858-864.

[12] Goering H.K., van Soest P.J., Forage fiber analysis (apparatus, reagents, procedures and some applications), in: Agric. Handb. 379, ARS USDA, Washington DC, USA, 1970, pp. 1-20.

[13] Guessous F., Rihani N., Kabbali A., Johnson L., Improving feeding system for sheep in a Mediterranean rain-fed cereals/livestock area of Morocco, J. Anim. Sci. 67 (1989) 3080-3086.

[14] Kemp J.D., Johnson A.E., Stewart D.F., Ely D.G., Fox J.D., Effect of dietary protein, slaughter weight and sex on carcass composition, organoleptic properties and cooking losses of lambs, J. Anim. Sci. 42 (1976) 575-583.

[15] Lanza M., Pennisi P., Priolo A., Faba bean as an alternative protein source in lamb diets: effects on growth and meat quality, Zootech. Nutr. Anim. 25 (1999) 71-79.

[16] Licitra G., Hernandez T.M., van Soest P.J., Standardization of procedures for nitrogen fractionation of ruminants feeds, Anim. Feed Sci. Tech. 57 (1996) 347-358.

[17] Makkar H.P.S., Goodchild A.V., Quantification of tannins, in: A laboratory manual. International Center for Agricultural Research in the Dry Areas, Aleppo, Syria, 1996, 25 p.

[18] Menke K.H., Steingass H., Estimation of the energetic feed value from chemical analysis and in vitro gas production using rumen fluid, Anim. Res. Dev. 28 (1988) 7-55.

[19] Minitab, Reference manual, Minitab Inc., State College, PA, USA, 1995.

[20] Priolo A., Lanza M., Biondi L., Pappalardo P. Young O.A., Effect of partially replacing dietary barley with $20 \%$ carob pulp on post-weaning growth, and carcass and meat characteristics of Comisana lambs, Meat Sci. 50 (1998) 355-363.

[21] Priolo A., Waghorn G.C., Lanza M., Biondi L., Pennisi P., Polyethylene glycol as a means for reducing the impact of condensed tannins in carob pulp: effects on lamb growth performance and meat quality, J. Anim. Sci. 78 (2000) 810-816.

[22] Solomon M.B., Kemp J.D., Moody W.G., Ely D.G., Fox J.D., Effect of breed and slaughter weight on physical, chemical and organoleptic properties of lamb carcasses, J. Anim. Sci. 51 (1980) 1102-1107.

[23] Surra J., Purroy A., Munoz F., Treacher T., Lentils and faba beans in lamb diet, Small Ruminant Res. 7 (1992) 43-49.

[24] Young O.A., Berdaguè J.L., Viallon C., RoussetAkrim S., Thériez M., Fat-borne volatiles and sheepmeat odour, Meat Sci. 45 (1997) 183-200.

[25] Zygoyannis D., Stamataris K., Kouimtzis S. Doney J.M., Carcass composition in lambs of Greek dairy breeds of sheep, Anim. Prod. 50 (1990) 261-269. 